\author{
Yao Qinhua i Wang Song \\ Šangajska akademija društvenih nauka
}

\title{
Kineski srednjoevropski i istočnoevropski 16+1 mehanizam saradnje
}

\begin{abstract}
Sažetak
Inicijativa „Pojas i put” jeste skraćenica naziva „Ekonomski pojas puta svile” i „Morski put svile u dvadeset prvom veku". Pokrenuo ga je predsednik Si Đinping tokom posete Kazahstanu u septembru 2013. godine. „Pojasni put” prolazi preko kontinenata Azije i Evrope, povezujući pulsirajuće ekonomije istočne Azije i razvojnim krugom evropske ekonomije, i državama koje su u okruženju sa ogromnim potencijalom za ekonomski razvoj. Srednja i Istočna Evropa (CEE) predstavlja neizbežni deo kopnenog evroazijskog mosta, i poseduje važne strategije i ekonomski status zahvaljujući svojoj zdravoj društvenoj sredini i humanističkim kvalitetima. Prirodno se pojavio kao ključna ekonomska veza duž „Pojasa i puta” nakon pokretanja Inicijative, još više naglašavajući značaj kineske - CCE 16+1 kooperacijskog mehanizma.
\end{abstract}

Ključne reči:

Mehanizam „16+1”, projekat „Pojas i put”, međunarodni rizici

\section{POSTIGNUĆA MEHANIZMA SARADNJE $16+1$}

Prvi Poslovni forum između Kine i srednjoevropskih i istočnoevropskih zemalja (CEEC) $)^{1}$ Održao se u Budimpešti, Mađarska, 2011, uspostavivši saradnju

\footnotetext{
Xinhuanet: Govor predsednika Ksi Đinpinga u Nazarbajevskom univerzitetu, septembar 8, 2013. http://www.xinhuanet.com/politics/2013-09/08/c_117273079.htm (Last date online: February 13, 2018).
} 
između Kine i 16 CEE država (što je skraćeno „16+1”). Kasnije, u aprilu 2012. dve strane su formalno ustanovile "16+1" kroz - regionalnu platformu saradnje. Inicijativa „Pojas i put” dobro je prihvaćena od strane 16 CEE država. Ona zahteva ogromne investicije i tehnologije iz inostranstva za njihov sopstveni ekonomski razvoj i, zahvaljujući tome, njima su dati povoljni ekonomski uslovi kako bi se razvila spoljna trgovina i saobraćaj. To je, zahvaljujući njihovim geoekonomskim prednostima što se tiče povezivanja Baltika na severu, zapadne Evrope na zapadu, Mediterana na jugu i zapadne Azije na istoku. Mehanizam saradnje „16+1" uključen je u opšti okvir Inicijative „Pojasa i puta", što je integralni deo evroazijskog ekonomskog kruga.

\section{1. Česti sastanci na visokom nivou, komunikacija bliske politike}

U aprilu 2012, Drugi kineski poslovni forum sa CEEC održan je u Varšavi, Poljska, održavajući se istovremeno sa prvim zajedničkim sastankom među liderima Kine i CEEC zemalja. U Bucharest Guidelines for Cooperation between China and Central and Eastern European Countries, izdatom u novembru 2013, lideri 17 zemalja organizovali su niz sastanaka za 16+1 premijere vlada. Ovi stalni samiti intenzivirali su politiku komunikacija među 17 zemalja i ojačanih odnosa i saradnje među njima (Tabela 1) da bi se dalje promovisala saradnja 16+1 u svim sektorima, Guidelines for China-CEEC Cooperation, izdat tokom svakog godišnjeg samita, objaviće napredak i viziju buduće saradnje, saradnje 16+1 kao dodatak tome.

Tabela 1.

\begin{tabular}{|c|c|c|c|}
\hline Naziv samita & Datum & Mesto & Najvažniji rezultati \\
\hline $\begin{array}{l}\text { Samit Kine } \\
\text { i država CEEC }\end{array}$ & april 2012. & $\begin{array}{l}\text { Varšava, } \\
\text { Poljska }\end{array}$ & $\begin{array}{l}12 \text { mera za promovisanje prijateljske } \\
\text { saradnje izmedu Kine i država CEEC }\end{array}$ \\
\hline $\begin{array}{l}\text { Drugi samit } \\
\text { „16+1" država }\end{array}$ & $\begin{array}{l}\text { novembar } \\
2013 \text {. }\end{array}$ & $\begin{array}{l}\text { Bukurešt, } \\
\text { Rumunija }\end{array}$ & $\begin{array}{l}\text { Uputstva iz Bukurešta o saradnji iz- } \\
\text { među Kine i srednjoevropskih } i \text { istoč- } \\
\text { noevropskih država }\end{array}$ \\
\hline $\begin{array}{l}\text { Treći samit Kine } \\
\text { i CEEC država }\end{array}$ & $\begin{array}{l}\text { decembar } \\
2014 .\end{array}$ & $\begin{array}{l}\text { Beograd, } \\
\text { Srbija }\end{array}$ & $\begin{array}{l}\text { Beogradska uputstva za saradnju iz- } \\
\text { među Kine i srednjoevropskih } i \text { isto- } \\
\text { čnoevropskih država }\end{array}$ \\
\hline $\begin{array}{l}\text { Četvrti samit Kine } \\
\text { i CEEC država }\end{array}$ & $\begin{array}{l}\text { novembar } \\
2015 .\end{array}$ & $\begin{array}{l}\text { Suzohou, } \\
\text { Kina }\end{array}$ & $\begin{array}{l}\text { Teme iz sredine termina o saradnji } \\
\text { Kine i srednjoevropskih i istočno- } \\
\text { evropskih država, i Suzohou uputstva } \\
\text { za saradnju izmedu Kine i srednjo- } \\
\text { evropskih i istočnoevropskih država }\end{array}$ \\
\hline
\end{tabular}




\begin{tabular}{c|c|c|l}
\hline $\begin{array}{c}\text { Peti samit Kine } \\
\text { i CEEC država }\end{array}$ & $\begin{array}{c}\text { novembar } \\
2016 .\end{array}$ & $\begin{array}{c}\text { Riga, } \\
\text { Letonija }\end{array}$ & $\begin{array}{l}\text { Uputstva iz Rige za saradnju izme- } \\
\text { du Kine i srednjoevropskih i istočno- } \\
\text { evropskih država }\end{array}$ \\
\hline $\begin{array}{c}\text { Šesti samit Kine } \\
\text { i CEEC država }\end{array}$ & $\begin{array}{c}\text { novembar } \\
2017 .\end{array}$ & $\begin{array}{c}\text { Budimpešta, } \\
\text { Mađarska, }\end{array}$ & $\begin{array}{l}\text { Budimpeštanska uputstva za sarad- } \\
\text { nju između Kine i srednjoevropskih i } \\
\text { istočnoevropskih država }\end{array}$ \\
\hline
\end{tabular}

Izvor podataka: Ministarstvo inostranih poslova Narodne Republike Kine; http://www.fmprc.gov.cn.

U međuvremenu, Kina i CEEC države takođe su održale ministarske konferencije kako bi se diskutovalo o temama od zajedničkog interesa. Dve ministarske konferencije Kine i srednjoevropskih i istočnoevropskih država o promovisanju trgovine i ekonomske saradnje održane su, jedna posle druge, juna 2014. i juna 2016. Teme o kojima se diskutovalo na dve konferencije oslikavaju rezultate saradnje "16+1".

Tabela 2. Istorija Ministarske konferencije '16+1'

\begin{tabular}{|c|c|c|}
\hline $\begin{array}{c}\text { Naziv } \\
\text { konferencije }\end{array}$ & $\begin{array}{l}\text { Ministarska konferencija o Kini i } \\
\text { srednjoevropskih i istočnoevrop- } \\
\text { skih država o unapređivanju trgo- } \\
\text { vine i ekonomske saradnje }\end{array}$ & $\begin{array}{l}\text { Druga ministarska konferencija o } \\
\text { Kini i srednjoevropskih i istočno- } \\
\text { evropskih država o unapređivanju } \\
\text { trgovine i ekonomske saradnje }\end{array}$ \\
\hline Datum & jun, 2014. & jun, 2016. \\
\hline Mesto & Ningbo, Zhejiang & Ningbo, Zhejiang \\
\hline Tema & $\begin{array}{l}\text { Poboljšati pragmatičnu saradnju i } \\
\text { postići zajednički razvoj }\end{array}$ & $\begin{array}{l}\text { Otvaranje novog poglavlja za } 16+1 \\
\text { trgovinsku i ekonomsku saradnju, } \\
\text { koja se zasniva na ekonomskoj sa- } \\
\text { radnji zasnovanoj na novoj počet- } \\
\text { noj tački }\end{array}$ \\
\hline Glavne teme & $\begin{array}{l}\text { Širiti stepen trgovine, unapređi- } \\
\text { vanje trgovinske ravnoteže, pove- } \\
\text { ćavanje zajedničkog investiranja, } \\
\text { utvrđivanje ekonomske i trgovin- } \\
\text { ske saradnje, širenje finansijskih } \\
\text { kanala i utvrđivanje kooperacije } \\
\text { za infrastukturu }\end{array}$ & $\begin{array}{l}\text { Identifikovanje karakterističnih pro- } \\
\text { izvoda, razvijanje novih tačaka } \\
\text { razvoja za bilateralnu saradnju, } \\
\text { širenje oblasti saradnje, promovi- } \\
\text { sanje saradnje za kapacitet i izra- } \\
\text { du opreme, i stvaranje finansijskih } \\
\text { modela i novih modela za infra- } \\
\text { strukturnu saradnju }\end{array}$ \\
\hline $\begin{array}{l}\text { Glavni } \\
\text { zaključci }\end{array}$ & $\begin{array}{l}\text { Zajednički dokument ministarskih } \\
\text { konferencija Kine i srednjoevrop- } \\
\text { skih i istočnoevropskih država o } \\
\text { promovisanju trgovine i ekonom- } \\
\text { ske saradnje }\end{array}$ & $\begin{array}{l}\text { Ningbo deklaracija druge mini- } \\
\text { starske saradnje Kine i srednjo- } \\
\text { evropskih i istočnoevropskih dr- } \\
\text { žava o unapređivanju trgovine i } \\
\text { ekonomske saradnje }\end{array}$ \\
\hline
\end{tabular}

Izvor podataka: Ministarstvo trgovine Narodne Republike Kine; http://www.mofcom.gov.cn. 
Promovisane mehanizmom saradnje „16+1”, raznolike poslovne asocijacije i kooperativne organizacije predstavljene su jedna za drugom u poslednje vreme. 22. maja 2014. prva Konferencija Kina - CEEC o saradnji u turizmu održana je u Budimpešti, Mađarska, tokom koje je Koordinacioni centar asocijacije Kine i CEEC Asocijacije agencija za promociju turizma i biznisa zvanično je inaugurisana. 24. maja 2016. prvi sastanak na visokom nivou Kina - CEEC o saradnji u šumarstvu u Ljubljani, Slovenija, prihvatajući Akcioni plan za saradnju za mehanizam o koordinaciji u šumarstvu između Kine i CEEC. Stoga je Slovenija preuzela vođstvo u ustanovljavanju ovog mehanizma; Srbija u ustanovljavanju kinesko-CEEC asocijacije o kooperaciji u saobraćajnoj infrastrukturi; Poljska u ustanovljavanju izvršnog tela Biznis saveta Kine - CEEC sa Sekretarijatom naizmenično u Pekingu i Varšavi; Bugarska u ustanovljavanju Asocijacije Kina - CEEC za promovisanje poljoprivredne saradnje; Letonija u ustanovljavanju Asocijacije Kina - CEEC za kooperaciju u logistici; i Slovačka u ustanovljavanju Tehnološkog transfera virtuelnog centra Kine i CEEC zemalja.

\section{Kineski železnički ekspres - Benefiti brenda koji se pojavio}

Da bi se promovisao glatki tok robe između Kine i EU, kineska vlada je objavila u Viziji i akciji o zajedničkoj gradnji Ekonomskog pojasa puta svile u 21. veku i Morskom putu svile da "mi treba da ustanovimo mehanizme u smislu železničkog transporta i raščišćavanja lučke carine za koridor Kina - Evropa, da bi se kultivisao brend teretnih vozova Kina - Evropa, i da bi se konstruisao koridor transporta preko granice koji povezuje istočne, centralne i zapadne regije". Još od pokretanja prvog Yuxinou voza 28. januara 2011, Kineski železnički ekspres - teretni voz između Kine i Evrope - video je veliki napredak. Sa zajedničkim razumevanjem supervizije među državama duž te rute, i politika „Jedne deklaracije, jedne inspekcije i jednog oslobađanja”, volumen trgovine među „16+1" zemljama naglo raste. 8. juna 2016, kišobran brend je pokrenut, poznat pod imenom Kineski železnički ekspres ${ }^{2}$ (CR Ekspres, ili 中欧班列 na kineskom jeziku), što je ispratilo puštanje Petogodišnjeg plana kineskog železničkog ekspresa (2016). 8. oktobra prvi dizajn visokog nivoa, što specifikuje tri glavna izlaganja i sedam glavnih zadataka koji su potrebni da bi se izgradila sveobuhvatna CR ekspres servis sistem sa racionalnim izlaganjem, potpunim sredstvima, stabilni volumen tereta, adekvatnosti i efikasnosti, sigurnosti lakog toka do 2020. godine.

2 NDRC, MFA and MOFCOM. Vision and Actions on Jointly Building the Silk Road Economic Belt and the 21st-Century Maritime Silk Road, March 28, 2015; http://www.xinhuanet. com/world/2015-03/28/c_1114793986.htm (Last date online: February 12, 2018). 
U aprilu 2017, novi teretni vozovi koji povezuju Xi'an u Kini sa Budimpeštom u Mađarskoj počeli su zvaničnu operaciju. To putovanje pokriva razdaljina $9.300 \mathrm{~km}$ i traje ukupno 20 dana. Da bi se optimizovala efikasnost operacije CR ekspresa, Kineska železnička kooperacija potpisala je Sporazum za dalju saradnju u kinesko-evropskom vozovima, Blok vozovi, među železnicama u Kini, Kazahstanu, Mongoliji, Rusiji, Belorusiji, Poljskoj i Nemačkoj sa železničkim kompanijama u relevantnim državama 20. aprila 2017. - prvi kooperativni sporazum između CR ekspresa i železnički departman duž te rute.

Još od početka, koji se desio pre šest godina, CR ekspres video je 17 kružnih puteva u 2011. godini, 42 u 2012, 80 u 2013, 308 u 2014, 815 u 2015. i 1702 u 2016. U 2017. video se nagli porast u broju puteva, do 3.673, kao i brza ekspanzija u okviru usluga. Do sada, 38 kineskih gradova, voz CR ekspres stiže do 36 gradova, u 13 evropskih gradova - rast u 23 grada u 5 država u poređenju sa 2016. Sve ukupno, sada funkcioniše 61 linija brzinom od $120 \mathrm{~km}$. Vreme putovanja skratilo se sa 20 -ak dana na kraće od dve sedmice za mnoga putovanja. Troškovi trajanja umanjeni su za 40 procenata i efikasnost operacije nastavlja da raste. Uz to, količina dobara biva obogaćena IT proizvodima kao što su mobilni telefoni i kompjuteri, odeća, cipele i šeširi, automobili i delovi za automobile, seme, vino, kafa, i drvo, pokrivajući mnogostruke aspekte proizvodnje i načina života duž te rute. ${ }^{3}$

Brzi razvoj CR ekspresa takođe je motivisala trgovinu između Kine i CEEC i druge evropske države. U januaru 2018. teretni voz od Qinzhou u Guangxi do Mataszewicze u Poljskoj krenuo je na svoj prvi put, prevozeći robu iz azijske države i otvarajući novi put za internacionalnu zemlju i morsku trgovinu kroz Guangxi do Evrope. ${ }^{4}$ Nippon Express takođe planira da otvori usluge transporta dobara iz Japana u Evropu kroz Kinesku železničku mrežu. ${ }^{5}$

3 CRCT: http://www.crct.com/index.php?m=content\&c=index\&a=lists\&catid=22 (Last date online: January 10, 2018).

4 CR Express Qinzhou Maiden Trip with ASEAN Goods to Europe, January 18, 2018; https:// baijiahao.baidu.com/s?id=1589924377034319366\&wfr=spider\&for=pc (Last date online: January 25, 2018).

5 Reference News: Japanese Media: Japan-Europe Freight Transport Turns to Belt \& Road through CR Express, January 11, 2018; http://www.cankaoxiaoxi.com/ world/20180111/2251353.shtml (Last date online: February 12, 2018) 


\section{Pionirsko povezivanje železnicom, osnažujući saradnju putem izgradnje infrastrukture}

Železničko povezivanje predstavlja važno sredstvo za kinesku vladu da bi se promovisala Inicijativa „Pojas i put”. Povezanost između Kine i CCEC uključuje železnicu, autoputeve, avijaciju i prevoženje, kao i programe koji uključuju konstrukciju unakrsne granice, telekomunikacijskih sredstava i naftne i gas cevovode. Sa operacijom CR ekspresa, detaljan plan Koridora CEE još jednom je stavljen u prvi plan kada su kooperativni projekti između Kine i CEEC država bili implementirani.

U decembru 2015, zajednički napori država koje su uključene rezultirali su izgradnjom železničke pruge od Budimpešte, Mađarska, do Beograda u Srbiji. Železnička pruga duga $350 \mathrm{~km}$ od Mađarske do Srbije predstavlja projekat za saradnju Kine i CEEC. Modifikovana, kao elektrificiran dvostrukim tračnicama i za putnike i za teret železnica sa predviđenom brzinom od $200 \mathrm{~km} / \mathrm{h}$, nakon završetka, skratiće vreme putovanja između ova dva grada sa osam na tri sata. ${ }^{6}$ Kina je takođe učestvovala u konstrukciji važnih infrastrukturnih projekata, uključujući Makedonsko - Miladinovici - Štip ekspress put na Kičevo - Ohrid Exspreesway, Smolyac - Mateševo sekcija na autoputu Sever - Jug u Crnoj Gori, most preko reke Dunava u Beogradu, urbana sredstva za kontrolisanje poplava u Vroclavi, u Poljskoj, i Elektrana Stiner u Bosni i Hercegovini.

\section{Raznolika saradnja u trgovini i ekonomiji, glatki kanali za investiranje}

Ekonomska zona trgovine i saradnje predstavlja efektnu platformu za promovisanje Inicijative „Pojas i put”, za međunarodnu saradnju u industrijskom kapacitetu i proizvodnju opreme. Prilikom izgradnje takvih zona preko okeana na osnovu komercijalne operacije i za svrhu promovisanja međusobnih dobrobiti, kineska preduzeća igraju glavnu ulogu. Da bi se donele odluke u skladu sa tržištem treba uskladiti sa investicionom sredinom i politikom privlačenja države domaćina. Konstrukcija ovih zona ohrabruje preduzeća kako bi se investiralo i grade se fabrike u zemljama da bi se povećala zaposlenost i naplata poreza, da se prošire izvozi i međunarodna razmena, da se poboljšaju njihovi tehnički nivoi, da se promoviše zajednički razvoj za investitore i zemlje domaćine. Centralna evropska trgovina i logistička saradnja zone (CEEZ) postavljena je u Budimpešti, Mađarska,

21st Century Business Herald. China's First European Railway Infrastructure Commenced, December 7, 2017; http://m.21jingji.com/article/20171207/809f296868a7750dc3a0aeb82b4cac1f.html (Last date online: January 22, 2018). 
u projektu na visokom nivou organizovane od strane Shandong Provincial Vlade i implementirane od strane Shandong Imperial Investment Co., Ltd, pod Ministarstvom trgovine Narodne Republike Kine. Sa oblasti planiranja od $0.75 \mathrm{~km}^{2}$ i potpune investicije od 264.000.000 američkih dolara, CECZ se sada završilo u „Jednoj zoni, tri parka”, predstavljanja, i ustanovio je projekte kao što je Chinese Commodity Exchange \& Exhibition Center and the Chipper Port Logistics Park. ${ }^{7}$

CECZ treba da obezbede neprekidne usluge polazeći od izvoza - uvoza dobara, deklaraciju carine i inspekcije, logistike i distribucije i skladištenja finansija za preduzeća kojima je potreban tamošnji prostor. To takođe omogućava marketinške aktivnosti, kao što su sajmovi trgovine, pregovori u trgovini, promotivni sastanci za kineske proizvode i izložbene hale za kineske potrebe. Kao prva zona na državnom nivou za ekonomsku i trgovinsku saradnju u CEE, CECZ predstavlja važnog promotera za ekonomsku i trgovinsku kooperaciju između Kine i CEEC država. Ona je kreirala prilike za kineska preduzeća da lociraju investicione projekte i da se proširi trgovina, olakšavajući njihove „Idemo globalno" inicijative dok se smanjuju operativni troškovi, rizici za kontrolu i formiranje industrijskog klastera sa postepenim ekonomskim efektom.

Jedan važan uslov za zajedničku izgradnju Pojasa i puta između Kine i CEEC država jesu fondovi za smeštaj. Internacionalizacija Renminbi i pomoć Azijske infrastrukturne investicione banke i Fonda puta svile predstavljaju važne kanale za ovu svrhu. Dok već spomenuti entiteti još uvek ne pokrivaju CEEC države, Kina je ustanovila investicioni fond od tri milijarde američkih dolara da bi se promovisali projekti u CEEC. Kina je uvek bila posvećena ohrabrivanju 16 srednjoevropskih i istočnoevropskih država da koriste posebne zajmove koje odobrava i daje njihova sopstvena Vlada $u$ skladu sa EU i lokalnim zakonima i regulativama. Ta kineska preduzeća i finansijske institucije aktivno učestvuju u "javno-privatnom partnerstvu” (PPP) u takvim državama. ${ }^{8}$ Zasnovani na fazi 1 kineske-CEE investicionog Kooperacionog fonda, kineska Vlada je lansirala drugu fazu na količinu od jedne milijarde američkih dolara.

$7 \quad$ Refer to Belt and Road Portal. Central European Trade and Logistics Cooperation Zone in Hungary, February 4, 2017; https://www.yidaiyilu.gov.cn/qyfc/xmal/6052.htm (Last date online: February 12, 2018).

8 Refer to CECZ homepage. "http://www.cecz.org/menu_1.html" http://www.cecz.org/ menu_1.html (Last date online: January 23, 2018). 


\section{Pojačane grupe eksperata i specijalista razmene, bliske međuljudske veze}

Da bi se promovisalo istraživanje i akademske razmene koje se odnose na 16+1 Mehanizam kooperacije i bilateralni odnosi između Kine i 16 srednjoevropskih i istočnoevropskih zemalja, kineska Vlada započela je fond za istraživanje da bi ispitala veze između tih zemalja, u kojima Kina obezbeđuje RMB dva miliona svake godine. Ovaj fond ima za cilj da ohrabri i podrži programe istraživanja od strane eksperata i kod kuće i u inostranstvu, kao i učestvovanje kineskih naučnika na međunarodnim sastancima akademske javnosti, i radionice kineskih institucija za naučnike i mlade političare $u$ CEEC državama. To je produbilo međusobno razumevanje i postavilo temelje za dalju kooperaciju između Kine i CEEC država.

Da bi se istražila važnost, problemi i kontramere kod „16+1” Mehanizma kooperacije, dve strane su postavile Simpozijum na visokom nivou između Kine i CEEC grupe eksperata i specijalista. Na svakom od ova četiri simpozijuma izabrana je tema i njeni učesnici su učestvovali u diskusijama o promovisanju odnosa između Kine i srednjoevropskih i istočnoevropskih zemalja. Oni su delili stavove i ideje za doprinos da bi se postigao krajnji cilj. U decembru 2015, Kina - CEEC grupa eksperata i specijalista mreža uspostavljena je od strane Akademije za društvene nauke Republike Kine. Očekuje se da glavni stub za saradnju „16+1” bude Kooperativna platforma za grupu eksperata i specijalista između obe strane.

U smislu međuljudskih razmena, dijaloga ljudi - sa - ljudima i saradnje postali su sve dinamičniji, kako su i osvedočili poznati događaji, kao što su Godina promovisanja i kooperacije u turizmu, Godina ljudi - ljudima i kulturne razmene, i Godina medijske saradnje između Kine i CEEC država. U 16 CEE država nisu dozvoljene destinacije za kineske turiste, što je povećalo broj kineskih turista koji posećuju ovu regiju sa 280.000 na 930.000. Broj dvosmerne razmene studenata se udvostručio.

\section{KINESKA MEĐUNARODNA ODGOVORNOST I KONCEPT RAZVOJA}

U savremenom globalnom kontekstu značajnog razvoja, promena i prilagođavanje miru i održivosti ostaju tema u našoj epohi. Međutim, neizvesnosti i destabilišući faktori još uvek postoje u velikom broju. Još od globalne svetske krize iz 2008, svetska ekonomija se još uvek bori da se oporavi i suprotstavi trgovinskom protekcionizmu i ratu. SAD gubi svoju moć na svetskoj sceni, i globalna vlast traži nove snage i nove ideje. Kineska sveukupna 
nacionalna snaga naglo je porasla $u$ poslednjih $40^{9}$ godina posle njene reforme i otvaranja i njen BDP dolazi na drugo mesto u svetu. Međunarodna zajednica predviđa aktivnije kinesko učešće u međunarodnim poslovima. Sama Kina shvata da trenutno nema dovoljno robusnih vodećih sila za ekonomski razvoj sa regionalnim važnim tačkama koje se pojavljuju. U dobu u kome netradicionalne bezbedonosne pretnje, kao što su terorizam, kriza izbeglica, klimatske promene, nastavljaju da se šire, aktivno učešće Kine $\mathrm{u}$ globalnoj vlasti predstavlja važnu manifestaciju njene međunarodne odgovornosti.

\section{1. '16+1' mehanizam saradnje: Ishod recipročne} potražnje između Kine i CEEC država

Još od uspostavljanja diplomatskih odnosa između Kine i Evropske zajednice (EU) 1975. godine Kina je čvrsto podržavala proces evropske integracije, i poštovala je izabrane putanje razvoja evropskih zemalja. Posle Hladnog rata, nacije srednje i istočne Evrope počele su da se transformišu i „evropeizacija" je postala jednostrani trend. Međutim, zbog raznolikosti u nacionalnim snagama, ekonomskoj strukturi i geopolitici među srednjoevropskim i istočnoevropskim državama, one su zadržale različite pozicije u procesu EU integracije, vodeći do nedostatka koordinacije.

Sudeći po dubokim promenama međunarodne situacije i Kina i države srednje i istočne Evrope imaju jaku želju da prodube bilateralnu saradnju. Kineska ekonomija postigla je novi status quo i suočava se sa mnogostrukim pritiscima kao što je ekonomski pad, ekonomsko restrukturiranje i kapacitet globalizacije. Stoga je neophodno da se nastavi sa reformom u otvaranju i daljem proširivanju međunarodnog tržišta. Zemlje srednje i istočne Evrope predstavljaju važne mostove između istočnih i zapadnih tržišta. Njihov zdravi razvoj, široka perspektiva i određena vrsta komplementarnosti sa kineskom ekonomijom čine ih ključnom oblašću da sa njima Kina proširi svoju ekonomiju sa inostranstvom i trgovinske veze. Kina očekuje da CEE postane nova tačka razvoja u razvitku odnosa između Kine i EU. Za države CEE, investicija i kupovna moć država Zapadne Evrope pala je pod uticajem finansijskog kraha i krize duga iz 2008. Zadatak transformisanja i ekonomije srednjoevropskih i istočnoevropskih zemalja učinio je obaveznim nove kooperacijske mogućnosti i finansijske kanale. Kina - predstavnik novonastajućih ekonomija - učinila je impresivan učinak na sceni svetske politike

$9 \quad$ Ministarstvo inostranih poslova Republike Kine. Speech by Li Keqiang at the Sixth Summit of China and Central and Eastern European Countries, November 28, 2017; http://www. mfa.gov.cn/web/zyxw/t1514520.shtml (Last date online: January 11, 2018). 
i ekonomije. Privlačeći srednjoevropske i istočnoevropske zemlje da sarađuju. ${ }^{10}$

Međutim, razlike među zemljama istočne i srednje Evrope određuju da zahtevi i fokusi za saradnju sa Kinom umeju da variraju. Za Kinu to znači pravljenje izbora među CEE državama da identifikuju državu koju će preferirati ili se projekt prioritet ne slaže sa osnovnim principom jednakosti i međusobnog benefita. Nasuprot tome, CEE kao celina predstavlja mogućnost razvitka bilateralnih ekonomskih i trgovinskih odnosa sa Kinom, što je dobro ne samo za Kinu nego i za CEE države. U ovom kontekstu veoma je važno da dve strane vode sveobuhvatne strateške kooperacije i ustanove probojnu platformu. „16+1" mehanizam saradnje predstavlja posledicu ove zajedničke potrebe.

\section{Pojas i put: Promovisanje '16+1' mehanizma saradnje: ključni pokretač za implementaciju Inicijative 'Pojas i put'}

Inicijativa „Pojas i put” je kineski intelektualni doprinos teoriji i praksi globalnom vlasti. To je inspirisano od strane starog Puta svile, i obezbeđuje novi podsticaj i pokretač za ekonomsku globalizaciju u dvadeset prvom veku. Ona zbližava različite političke i ekonomske sisteme, različite resursa darivanja i različitih civilizacija. Pojas i put mogu da poboljšaju međusobnu povezanost među državama duž njega, promovišu ekonomski i društveni razvoj u Evroaziji, da podstaknu globalnu trgovinu i investicije i poboljšavaju živote širom sveta. „16+1" mehanizam saradnje predstavlja važan pokretač za implementiraje Inicijative „Pojas i put”. Kako je primetio premijer Li Keqiang na Šestom samitu Kine i CEEC, „16+1" mehanizam Kooperacije - koje se pojavilo u kontekstu globalizacije - u skladu je sa istorijskim trendom liberalizacije i olakšavanja trgovine i investicija. ${ }^{11}$

Na zajedničkoj promociji vođa Vlada u 17 zemalja, „16+1” mehanizam Kooperacije dao je značajne rezultate. Oni uključuju formulaciju MEDIUM TERM AGENDA za kooperaciju između Kine i srednjoevropskih i istočnoevropskih zemalja, ustanovljavanje 20 plus institucionalnih platformi za izmenu, planiranje nekoliko glavnih inicijativa (uključujući i železničku prugu Budimpešta - Beograd, Kina - Evropa kopno - More ekspres linija, i Jadransko

10 Yu Jun. China-CEEC Cooperation Mechanism: Current Situation and Improvement Path, International Studies, Edition 2, 2015, p. 121.

11 Ministry of Foreign Affairs of the People's Republic of China. Speech by Li Keqiang at the Sixth Summit of China and Central and Eastern European Countries, November 28, 2017; http://www.mfa.gov.cn/web/zyxw/t1514520.shtml (Last date online: January 11, 2018). 
more - Baltičko more - Crno more, saradnja morskih luka), predstavljanje više od 200 specifičnih mera. Kooperacija između Kine i srednjoevropskih $\mathrm{i}$ istočnoevropskih zemalja $\mathrm{u}$ investiranju, trgovini i turizmu videla je brzi napredak. Veoma je ugodno da se vidi kako Kina održava ekonomski razvoj od $6.5 \%$ u kontekstu sporog svetskog oporavljanja od ekonomske krize, koje stalno poboljšava dobrobiti i optimizovane strukture. U međuvremenu, CEE države su preradile negativni uticaj evropske krize duga, postižući ekonomski razvoj od preko 3\% u skorije vreme i postajući sektor koji se ističe u evropskom ekonomskom krugu. ${ }^{12}$

\section{PROBLEMI SA BILATERALNOM SARADNJOM}

Uprkos mnogim pozitivnim stranama, ovde ostaju neki nezadovoljavajući fenomeni u ekonomskim trgovinskim odnosima između Kine i CEE, koji zaslužuju ozbiljno razmatranje i tretman.

\section{Slab hardver na CR ekspresu; trgovinski disbalans}

CR ekspres je doživeo brzi razvoj od desetine putovanja godišnje u ranim danima do sadašnjih 3000 plus. Međutim, određeni problemi i dalje opstaju. Prvo, brzi razvoj doveo je do zakašnjenja u infrastrukturi. Tri tradicionalne CR ekspres luke Alatav, Mandžurija i Erenhot su u punom kapacitetu. Izgradnjom puteva Alatav ima perspektivu da ostvari zastoj dok čeka podršku iz Khorgos luke. Drugo, neuniformni železnički proračuni i nekonzistentne karantinske politike zemalja duž CR ekspresa dodaju prepreke i teškoće. Bilo koja promena u politici u okviru država može da utiče nepovoljno na operaciju CR ekspresa. Treće, CR ekspres se suočava sa problemima kao što je loše ciljana trgovina dobrima i odlazaka na sud tranzicionih tvrdnji, koji su prouzrokovani trgovinskom informacijskom asimetrijom; ovo zahteva komunikacije tržišnih informacija i koordinacije zakona i politika među državama duž te linije. Konačno, nebalansiranost kvantiteta dobara među predstojećim putovanjima i povratnim putovanjima otežava da mnogi vozovi budu profitabilni. Zbog nedostatka dobara u povratku, mnoga sredstva

$12 \quad$ Ministry of Foreign Affairs of the People's Republic of China. Speech by Li Keqiang at the Sixth Summit of China and Central and Eastern European Countries, November 28, 2017; http://www.mfa.gov.cn/web/zyxw/t1514520.shtml (Last date online: January 11, 2018). 
za čuvanje i držanje robe moraju se prodati u inostranstvu pošto budu istovarena. ${ }^{13}$

\section{Postojeće razlike među državama CEE; teškoće kooperacije u okviru granica}

Iza regionalne integracije država CEE leže sakrivene razlike u uslovima $\mathrm{u}$ kojima nacije žive. Spolja gledano, razlike među CEE državama pokrivaju jezik, kulturu, religiju, društvene običaje i tradicije, ekonomsku skalu i sopstveni identitet. Neke države čak i izbegavaju ime „srednja i istočna Evropa". Razlike u nazivima srednja Evropa, istočna Evropa, jugoistočna Evropa, zapadni Balkan, istočni Balkan, Evrozona i ne-Evrozona, EU države članice, države koje nisu članice EU, zemlje potencijalni kandidati za EU i države koje nisu potencijalni kandidati za EU - reflektuju probleme koji se nalaze ispod površine, kao što su geopolitičke preference i putevi razvoja. Međunarodne institucije, kao što je Evropska banka za rekonstrukciju i razvoj (EBRD), Svetska banka (WB) i Međunarodni monetarni fond takođe klasifikuju CEE države različito. Sama EU koristi različite strategije i političke instrumente da bi razvila odnose među CEE državama. U ovom svetlu, CEE države nisu uspele da se razviju u integrisanu stratešku snagu bez obzira na regionalno zajedništvo. Kao rezultat toga, njihove orijentacije i očekivanja u njihovim odnosima sa Kinom takođe su različita. Iz ovog razloga, Kina ima veće šanse da se susretne sa više poteškoća u razvijanju bilateralnih odnosa u samom kooperativnom okviru koristeći regionalni pristup CEE državama, što se naročito tiče specifične koordinacije politike.

\section{Veliki rizici na tržištu; nezdrave sredine za razvoj biznisa}

Iz makroperspektive tržišnih mehanizama, investicionih politika i pravnih sistema, u CEE državama je potreban napredak. Iz mikroperspektive, najprivlačnije tradicionalne visokokvalitetne korisne i vredne stvari CEE država umnogome su pod kontrolom država sa Zapada kroz privatizaciju tokom perioda tranzicije. Kada su kineski investitori ušli u ovu regiju u 21. veku, mogli su samo da traže nove tačke za investiciju i saradnju. Pored toga, CEE države koje su postale članice EU (ili to očekuju) pod ciljem su EU sistema i ulaska na EU tržište. Strukturalna zavisnost se neće promeniti preko noći, što neizbežno otežava stvari za preduzeća koja su u fondu Kine. Štaviše,

13 Kunlunce.com: Problems of the CR Express, May 19, 2017; http://www.kunlunce.com/ ssjj/guojipinglun/2017-05-19/116037.html (Last date online: January 22, 2018). 
siva ekonomija i dominirajuća korupcija u nekim CEE državama (naročito u jugoistočnim evropskim zemljama) otežavaju osnaživanje zakona i regulativa, donoseći još više rizika kineskim investitorima. ${ }^{14}$

\section{Dvostruko slojevita struktura EU ograničava ostvarivanje u potpunosti potencijalnih CEE država}

Kao najintegrisanija međunarodna organizacija u svetu, EU uživa status međunarodnog prava, i njene države članice imaju različit pravni status u odnosu na obične suverene države. Na primer, CEE države pokazale su pozitivan odnos prema povratku u Evropu posle Hladnog rata, i aktivno su se okrenule Kini posle Svetske ekonomske krize iz 2008. godine. Sa druge strane, kolektivni suverenitet EU preteže u odnosu na suverenitet CEE država i njenih država članica. Na ovaj način, EU može da ispuni svoju moć cenzure o Kina - Evropa projektima kooperacije, i može čak da spreči takozvano "neprihvatanje” projekata. EU ima bojazan od „16+1" kooperacije između Kine i CEE država, sumnjajući da Kina želi da podeli Uniju. Nemačka kancelarka, Angela Merkel, jednom je upitala zašto se Kina uključila u odvojene bilateralne razgovore sa Srednjom i Istočnom Evropom. Kada je zajednička komunikacija o sastanku između Kine i CEE državama predstavljena u EU da bi se revidirala unapred, EU je zvanično zauzela stav protiv asociranja za „dugoročan i institucionalizovani kinesko-CEE odnos”. Da se sumira, "16+1" kooperacijski mod biva subjekat više nivoa struktura EU i dualnih identiteta EU članica.

\section{REFLEKSIJE NA POJAČAVANJU "16+1" MEHANIZMA KOOPERACIJE}

Iako postoje, još uvek, mnogi problemi u kooperaciji Kine i CEE država, "16+1" mehanizam kooperacije nastaviće da funkcioniše jednom kada bude započeo, ne kao CE ekspres. U stvari, upravo takvi suprotni faktori koji su ciljani utiču da obe strane poprave trgovinu i investicionu sredinu.

14 Liu Zuokui. China-CEE Cooperation: Problems and Countermeasures, International Studies, Edition 5, 2013, pp. 78-80. 


\section{Politička komunikacija i istraživanje zajedničkih interesa}

"16+1" mehanizam kooperacije smešta mnoge države učesnice i uključuje mnoge vlasnike, otežavajući na takav način da se ugodi svim ukusima. U ovom svetlu, zdravo slaganje makrorazvoja planira se na strateškom nivou i postaje vrlo važno. Princip „16+1” mehanizam kooperacije jeste zajednički benefit; ne bi trebalo da se fokusiramo na kineske nacionalne interese, ali ali je poželjno upoznati se sa planovima za razvoj 16 CEE država. Moramo posvetiti pažnju EU strateškoj viziji za razvoj CEE, i razumeti i zadovoljiti interese vanteritorijalnih snaga u regiji. U strateškom slaganju kooperacije između Kine i 16 CEE država, razlike u ekonomskoj skali, razvojnom statusu i nacionalnim interesima biće uzeti u razmatranje. Umesto da se lociraju „vodeće države” od ovih 16, mi ih posmatramo kao jedan entitet. Tretiramo svaku od njih kao poprilično takvu da bi se podigao njihov sveukupni status na međunarodnoj pozornici. Takođe pripisujemo veliku važnost varirajućim interesima tih 16 zemalja. Na primer, industrijska kooperacija 16 CEE država može koordinirati zdravo $u$ istoj industriji da bi se izbegla međunarodna konkurencija. Trebalo bi da sarađuju sa Kinom iz perspektive benefita integralnog regionalnog razvoja, i da se daje puno pravo njihovim sopstvenim industrijskim prednostima.

\section{Podrška od strane finansijskih usluga; ustanovljavanje platformi za investiranje i finansiranje}

Većina od 16 CEE država suočavaju se sa problemima kao što je slaba infrastruktura, strog pristup investicijama, visok investicioni rizik i nedovoljno razvijene finansijske usluge. Kao država u razvoju, Kina takođe nema dovoljno iskustva u organizovanju i upravljanju vlasti u trgovini finansijskih polja. Stoga je za dve strane neophodno sprovesti diskusije i preuzimati kooperaciju u ovom smislu. Na polju finansijskih usluga, Kina bi trebalo da promoviše internacionalizaciju RMB intenzifikacije svoje finansijske kooperacije sa CEE državama. Ovo uključuje proširivanje bilateralne razmene valute i lokalno utvrđivanje valute, koji pomažu kompanijama iz država CEE da se izvrše Panda Bonds u Kini, i da se podrže finansijske institucije na obe strane organizujući i vodeći RMB finansiranje. Obe strane mogu dalje da istražuju višestruke forme investiranja i finansiranja zasnovanih na tržištu da bi se obezbedila finansijska vitalna veza koja je neophodna za kooperaciju. ${ }^{15}$

15 Ministry of Foreign Affairs of the People's Republic of China. Speech by Li Keqiang at the Sixth Summit of China and Central and Eastern European Countries, November 28, 
Na polju investicija i trgovine, Kina bi trebalo da radi sa 16 CEE država da bi se pojednostavile procedure i umanjili troškovi transakcije; da se spusti prag investicija i umanjiti tarifne barijere; da se ustanove zone za trgovinu i procesuiranje i demonstracijske zone, da bi se povećala trgovina i investicione kooperacijske platforme; da bi se ohrabrio razvoj svih vrsta investicija i trgovinskih informacionih platformi. Zdrava biznis platforma trebalo bi da se uspostavi kroz zajedničke napore vlada ovih 16 zemalja.

\section{Konsolidovanje kooperacije sa infrastrukturnim projektima}

Sa železničkom prugom Budimpešta - Beograd, prelaskom reke Dunav preko mosta u Beogradu, kooperacija između dve strane $u$ infastrukturi bila je unesena kao tačka u „16+1" mehanizmu kooperacije. To je delimično zbog činjenice da CEE države imaju veće potrebe za infrastrukturom i investicionim propustom i zahtevaju kinesku tehničku i finansijsku podršku. To je takođe blisko povezano sa ovim iskustvom - Kina je prikupila u infrastrukturu i prekookeansku investiciju tokom četrdeset godina reforme i otvaranja Kine prema svetu. Istorija kineske diplomatije ocrnjena je primerima poboljšanja lokalnih uslova saobraćanja i promovisanja razvoja bilateralnih odnosa kroz infrastrukturne investicije. Projekti infrastrukture nose velike investicije, duga trajanja u izradi konstrukcija, i duge periode isplativosti, i tako imaju veću stabilnosti nego oni u drugim oblastima. U svetlu ovoga, "16+1" mehanizam kooperacije u infrastrukturi konstrukcije u potpunosti je kvalifikovano kao važnost ljudi za kooperaciju između Kine i CEE država. Kina bi trebalo da nastavi da širi infrastrukturne investicione projekte u CEE iz zemaljskog transporta (kao što su putevi, železničke pruge i mostovi) do morskog transporta i aviosaobraćaja (kao što su luke i aerodromi). U liniji sa principima međusobnog benefita, uzajamne konsultacije, konstrukcije, Kina bi trebalo da sa državama CEE sagradi relativno kompletne transportne mreže za bilo koji projekat, od čega će imati dobrobit i lokalni ljudi, ali i dugoročan razvoj bilateralnih odnosa.

\section{Isticanje međuljudske povezanosti i sveobuhvatne kulturne razmene}

Međuljudska povezanost je jedna od „pet konekcija” Inicijative „Pojas i put". Kao što je predsednik Si Đinping rekao, prijateljstvo - koje se izvodi iz bliskog kontakta među ljudima - drži ključ zdravih međudržavnih odnosa. Međuljudska povezanost promoviše prijateljstvo i učvršćuje međusob-

2017; http://www.mfa.gov.cn/web/zyxw/t1514520.shtml (Last date online: January 11, 2018). 
no razumevanje, i takođe igra ulogu u pojačavanju ekonomske kooperacije. Promovisanje interpersonalne povezanosti može da obezbedi platformu za poboljšavanje razmena i međusobne saradnje među nacijama i za gradnju zajedničkog kulturnog konteksta za širu zajednicu sa sličnom sudbinom. Da bi se postigao „16+1” ideal interpersonalne povezanosti, moramo započeti dijalozima i razmenama u oblasti nauke, obrazovanja, zdravlja i turizma i zatim to razdeliti na druge aspekte "16+1" mehanizma kooperacije. Na Šestom samitu Kine i CEEC, premijer Li Keqiang predložio je označavanje 2018. godine kao godine saradnje među lokalnim vlastima i lokalnim preduzećima. „Radujemo se sve većem učešću u „16+1” Asocijaciji guvernera provincija i regija od strane lokalne vlasti sa obe strane i nadamo se svim dimenzionim platformama pogodnim za čvrst i dubinski razvoj". ${ }^{16}$

Kina bi trebalo da Godinu lokalne saradnje uzme kao šansu da se proširi kulturna razmena sa CEE državama od nivoa države do lokalnog nivoa, i da se osnaži međusobno razumevanje dve strane.

Da sumiramo, saradnja CEEC predstavlja važan deo kineskih inostranih odnosa. To je bilateralna kooperacija koja pokazuje dugu vitalnost, kao što je prikazano sadašnjom praksom. Kina će preuzeti širu perspektivu za poziciju "16+1" u „velikoj igri" učestvovanja u međunarodnoj vlasti, kao i u dugogodišnjem cilju građenja globalne zajednice koja deli istu sudbinu. Objektivno govoreći, prostor za kooperaciju Kina - CEE jeste velika, i dizajn ima tendenciju da bude optimističan. Međutim, izazovi i teškoće sa kojima se ona suočava podjednako su veliki. Stoga, da bi se promovisao "16+1" mehanizam saradnje, moramo se držati koncepta Inicijative „Pojas i put”. To uključuje povezivanje sa razvojem planova država CEE i pravilnog zatvaranja svih zahteva sa projekata u „16+1" mehanizmu kooperacije. To će uključiti kretanje ruku pod ruku politika komunikacije, traženja podrške za finansijske usluge, konsolidacije infrastrukturnih projekata, kulturne razmene, stvaranja novih oblasti za saradnju i širenja horizonata i razvoja.

Prevod sa engleskog jezika: Jelena P. Đorđević

$16 \quad$ Ministry of Foreign Affairs of the People's Republic of China. Speech by Li Keqiang at the Sixth Summit of China and Central and Eastern European Countries, November 28, 2017; http://www.mfa.gov.cn/web/zyxw/t1514520.shtml (Last date online: January 11, 2018). 